University of Nebraska - Lincoln

DigitalCommons@University of Nebraska - Lincoln

Faculty Publications from the Harold W. Manter Laboratory of Parasitology

6-2001

\title{
Parasite Systematics in the 21st Century: Opportunities and Obstacles
}

Daniel R. Brooks

University of Toronto,dnlbrooks@gmail.com

Eric P. Hoberg

United States Department of Agriculture, eric.hoberg@ars.usda.gov

Follow this and additional works at: https://digitalcommons.unl.edu/parasitologyfacpubs

Part of the Parasitology Commons

Brooks, Daniel R. and Hoberg, Eric P., "Parasite Systematics in the 21st Century: Opportunities and Obstacles" (2001). Faculty Publications from the Harold W. Manter Laboratory of Parasitology. 353. https://digitalcommons.unl.edu/parasitologyfacpubs/353

This Article is brought to you for free and open access by the Parasitology, Harold W. Manter Laboratory of at DigitalCommons@University of Nebraska - Lincoln. It has been accepted for inclusion in Faculty Publications from the Harold W. Manter Laboratory of Parasitology by an authorized administrator of DigitalCommons@University of Nebraska - Lincoln. 


\section{Parasite systematics in the 21st century: opportunities and obstacles}

\author{
Daniel R. Brooks and Eric P. Hoberg
}

\begin{abstract}
Taxonomic names and phylogenetic hypotheses are indispensable tools for modem biological research, both basic and applied. Likeall disciplines, parasitology suffers from the 'taxonomic impediment' - aglobal shortage of professional taxonomists and systematists. Only a fraction of the species of parasites on this planet have been identified, and the evolutionary relationships of only a minority of thoseare understood; thus, information on how to manage parasite biodiversity, including known and potential disease agents, is incomplete. A renewal of systematic parasitology has a key role in redefining the relationship between mankind and the organisms whose biology fascinates us so much.
\end{abstract}

Asthe21st century begins, interest in parasites has never been greater. Parasites are becoming recognized as significant players in theevolutionary gameand are seen as excellent model systems for general evolutionary studies ${ }^{1,2}$. In addition, parasitic disease of humans, livestock and wild biodiversity represents a major concern for most countries. Whether an acutecrisis or a chronic condition is being faced, thebiodiversity crisis is on a scalegreater than onecould haveimagined 50 years ago. Increasingly, discussions about managing the biodiversity crisis indudeparasitismand parasitology.

\section{Valuing systematics}

Systematists providetwo kinds of information. Thefirst of theseis thenames and characteristics of all known species. Species areessential elements of biodiversitygenealogical information systems that storeand transmit theinformation leading to theemergence of ecosystems with their complex interactions. Without systematics, biological science could not proceed. All biological research begins with one or morenames of species, and it is systematists whomake certain that everyoneknows what names such as Plasmodium falciparum or Schistosoma mansoni mean when they aretalked about. Second, systematists al so provide the framework for comparativestudies in basicand applied biology. Thepredictable parts of biological systems are thoseelements, both form and function, autecological and synecological, that havepersisted through evolutionary time ${ }^{1,3,4}$

TheConvention on Biological Diversity $(C B D)^{5}$ designated species as the fundamental units of biodiversity, and ecosystems management and sustainabledevelopment as containing the organizing principles for managing gl obal biodiversity. Biologists and ecosystems managers alikequickly realized that the current inventory of the world's species was far toolimited to implement the CBD mandate properly and that a crucial shortage of trained taxonomists - the so-called taxonomic impediment - contributed directly to the problem ${ }^{6-11}$. The Conference of the Parties (COP) to the CBD has endorsed a Global Taxonomy I nitiative (GTI) to improve taxonomic knowledgeand capacity to further country needs and activities for the conservation, sustainable useand equitablesharing of benefits and knowledge of biodiversity ${ }^{12}$. The initiative has threecomponents, and each onewill be discussed in turn.

\section{Systematic inventory}

The CBD mandatestates that all signatories undertakea national inventory of their biodiversity resources. Such national inventories arebiodiversity development and conservation projects, a means for restoring global taxonomic capacity. Regardless of the focus of any inventory, the GTI mandates guidelines for choosing priority taxa for such inventories. Parasites satisfy all those criteria ${ }^{13-16}$, as outl ined below.

Taxa should be intrinsically important to humans Parasites areagents of di sease in humans, livestock and wild ifeand have consequent socio-economic significance. Knowledgeabout their lifestyleis particularly important when therisk of loss of biocontainment by introduced species is being assessed. Changes in parasitelifestyleas a result of introduced species could be dueto a number of factors. For example, parasites of introduced species might move intotheagricultural landscape or wildlands and switch to native hosts, or perhaps parasites of native species move out of the agricultural landscape or wildlands and infect theintroduced, economically important host species. A less-common factor could involvelocal peopleand tourists sharing parasites and parasitic diseases between themselves and between human and non-human hosts. Some parasitespecies might even providerevenueas model systems for pharmaceutical companies or as biocontrol agents.

Taxa should be intrinsically important to ecosystems that humans want to preserve

Parasites aresignificant regulators of host populations and are potent agents that maintain the integrity and stability of ecosystems. Complex feedback loops involving parasites, herbivores and habitat structure in ruminant grazing systems further indicatethesignificance of parasites as determinants of community structure. Parasites can also be important mediators of host behaviour. I ntroduced parasites can have unpredictableand deleterious impacts on nativespecies of hosts. It is therefore important to be able quickly to distinguish nativefrom introduced parasitespecies. 
Taxa should provide efficient means of learning something of importance

Parasites, especially thosethat havecomplex lifecycles involving morethan oneobligatehost, areindicators of stabletrophicstructure in ecosystems. This is because all the biotic components necessary for completion of the lifecydemust co-occur regularly in order tomaintain any given parasitespecies. Knowing thecomplement of parasitespedies inhabiting any given host thus provides a means of rapid assessment of the breadth and form of trophic interactions of host species. Parasites arekey to understanding the context of gl obal change.

Taxa should be geographically widespread

Many parasitetaxa are widespread geographically. At thesametime, they are highly local ized with respect to infecting particular hosts, which themsel ves can be thefocus of particular inventory activities.

\section{Taxa should provide opportunity for international} networking

Parasitesystematics is in serious troubleworldwide Laboratories throughout the world have eroded the infrastructurefor taxonomy and systematics at a crucial time. New survey opportunities and recognition of theimportance of parasites might stimulateinternational collaboration and recognition of theneed for the development or renewal of systematics infrastructurein every country.

\section{Predictive classifications}

A crucial element in preserving biodiversity within the context of the CBD is managing information about the 1.7 million species currently known, as well as those yet to bediscovered. Theframework for such information systems must includethecapability of making predictions about the characteristics of species based on what is known about the biology of close relatives. This requires knowledge of phylogenetic relationships; phylogenetic dassification systems are themost effectiveframework for predictive information systems about organisms and their place in the bi osphere ${ }^{6,15,17}$. Although systematists have madegiant leaps forward in understanding the interrelationships of life, phylogenetic hypotheses are still lacking for many groups. Diversitas, the United Nations Environment Programme (UNEP) in biodiversity, proposes to co-ordinateinternational research to achievea phylogenetic framework for all of liferesolved to thefamily level by theyear 2010. Parasitology quietly leads the way in this effort. For example, phylogeneticanalyses of the parasitic platyhel minths began appearing in 1985 (Refs 18,19), and today the initial skel eton of a phylogenetic treefor all theparasiticplatyhel minths to family level is available $\mathrm{e}^{1,20,21}$. There is still much room for discussion and improvement, but parts of parasi tology aremore than a decade ahead of the SA2K -I agenda.

Thepast decadehas seen theintegration of phylogeneticinformation in all areas of evolutionary research and in a growing number of areas of applied research, thus providing common ground to servethe professional agendas of evolutionary biologists and ecologists, as well as of biodiversity and conservation managers. Using phylogenetic frameworks tomake predictions can cut thetimeand costs of research and development, or of planning and prioritization ${ }^{15,22}$. Phylogenetic study of parasites can help assess the suitability of proposed biological control agents, recognize introduced species and predict the epidemiology of emergent diseases. I ndeed, understanding theevolutionary basis of disease resistance will comefroma comparison of closely related host species, oneresistant and theother susceptibletoa given pathogen, just as understanding theevolutionary basis for causing disease will come from comparing closely related parasites, one pathogenicand theother not.

Managing systematic knowledge bases Electronic data handling and inter-linked knowledge systems arebecoming the principal mediumfor all activities associated with applying systematic information in biodiversity studies and policies. The Organization for Economic Co-operation and Development (OECD) MegascienceF orum dedared this crucial need for systematicinformation a global priority in mid-1998. Parasitesystematists could contribute significantly tothis area, establ ishing phylogenetic and species homepages, and on-lineidentification guides and keys. Thephylogenetichome pages could provide inter-linked phylogenetictrees, modified periodically as needed, for all groups of parasites, whereas thespecies home pages could provideuseful information on each species. Thesesections could indude: 'what is it?' (and 'how can it bedistinguished from others?'), (2) 'whereis it?', and (3) 'what is itsnatural history?'Theon-line identification guides and keys could bedesigned toaid a largeuser community.

\section{Seeing and overcoming the taxonomic impediment in parasitology}

Comparativestudies using phylogenetic information haveappeared in virtually every area of biology during the past decade, including applied research in parasitology 23,24 . However, the primary limiting factor in all comparativestudies, both basic and applied, is a shortage of robust estimates of phylogeny ${ }^{25}$. This is because enthusiasm for using phylogenetic insights to further research has outrun theavailability of professional systematists. What do professional systematists offer non-systematists? They aretrained to amass and assess various forms of data, and are thus abletogenerate combined analyses using information from many different sources ${ }^{24,26-28}$. Systematists can also provide themost robust possible interpretation of phylogenetic results, helping researchers avoid theembarrassment of claiming support for one particular theory when their published data actually support theopposite ${ }^{29}$. 
The growing number of phylogenetically informed studies in basicand applied parasitol ogy highlights someharsh realities. First, although their number is growing, well supported phylogenies arestill rare; second, the groups that haveattracted phylogeneticists are rarely the groups that have attracted nonsystematists; and third, the number of active systematists decreases yearly. The solution to these problems requires a large amount of support from nonsystematists, for example(1) supporting thetraining and hiring of moresystematists, (2) providing more support for museum collections and museum systematists, and (3) becoming better versed about phylogenetic methodology. Surely it is moretime and cost-effective for modern molecular laboratories in tropical medicineand publichealth to hireprofessional systematists than to produce poor phylogenetic trees that will need to bere-donetoachievestable results? Systematists, for their part, must providemoreand larger databases, integrating all avai lablemolecular and morphological data; encouragestudents towork on groups that areimportant to non-systematists; and develop better ways to explain their ideas toa naive, but enthusiastic, audience.

In an effort to focus attention on the value of the taxasphereand promote the GTI, DIVERSITAS has designated 2001-2002 as the I nternational Biodiversity Observation Year (IBOY). One of the projects sanctioned by the IBOY steering committee is an inventory of the parasites of stickleback fishes worldwide, and is led by David Marcogliese, the 2001 winner of the Henry Baldwin Ward Medal of the American Society of Parasitologists. ThelBOY is an excellent opportunity for coalitions of international, national and local political, social development and environmental agencies to providea fuller inventory and better knowledge of the parasites on this planet. Perhaps theWorld Federation of Parasitol ogists and its subsidiary societies could endorse ongoing parasiteinventory projects throughout theworld during 2001-2002 as a sign of their commitment to systematic parasitology.

\section{Concluding remarks}

Saving biodi versity and promoting human socioeconomic development is a complex issuethat requires networks of both peopleand research programs. Networks requirea common languageand discourse, as well as collaborativedevelopment of theory and research programs. Modern systematists arethemasters of a language powerful enough to facilitate such necessary discourse.
13 Hoberg, E.P. (1997a) Phylogeny and historical reconstruction: host-parasite systems as keystones in biogeography and ecology. In Biodiversity II: Understanding and Protecting Our Biological Resources (Reaka-Kudla, M.L. et al., eds), pp. 243-261, J oseph Henry Press

14 Hoberg, E.P. (1997b) Parasite biodiversity and emerging pathogens: a role for systematics in limiting impacts on genetic resources. In Gl obal Genetic Resources: Access, Ownership and Intel lectual Property Rights (Hoagland, K.E. and A.Y. Rossman, eds), pp. 71-83, Association of Systematics Collections, Washington, DC

15 Brooks, D.R. and E.P Hoberg (2000) Triage for the biosphere: The need and rationale for taxonomic inventories and phylogenetic studies of parasites. Comp. Parasitol. 68, 1-25

16 Brooks, D.R. et al. Parasitos y la biodiversidad. In Enfoques Contemporaneos para el estudio de la Biodiversidad (Hernandez, M.H. et al., eds), Universidad Nacional Autónoma de Mexico (in press)

17 Simpson, B.B. and Cracraft, J . (1995) The science of biodiversity. BioScience 45, 670-672

18 Brooks, D.R. et al. (1985) The phylogeny of the Cercomeria Brooks, 1982 (Platyhelminthes). Proc. Helminthol. Soc. Wash. 52, 1-20

19 Brooks, D.R. et al. (1985) Phylogenetic analysis of the Digenea (Platyhelminthes: Cercomeria) with comments on their adaptiveradiation. Can. J . Zool. 63, 411-443

20 Littlewood, D.T.J . et al. (1999) The interrelationships of all major groups of platyhelminthes: phylogenetic evidence from morphology and molecules. Biol. J . Linn. Soc. 66 75-114

21 Littlewood, D.T.J . and Bray, R.A., eds The Platyhelminthes - Phylogenetic Perspectives, Taylor \& Francis (in press)
22 Brooks, D.R. (1998) Triage for the Biosphere. In TheBrundtland Commi ssi on's Report - 10 Years (Softing, G.B. et al., eds), pp. 71-80, Scandinavian University Press

23 Hoberg, E.P. and Lichtenfels, J .R. (1994) Phylogenetic systematic analysis of the Trichostrongylidae (Nematoda) with an initial assessment of coevolution and biogeography. J . Parasitol . 80, 976-996

24 Nadler, S.A. and Hudspeth, D.S.S. (2000) Phylogeny of theAscaridoidea (Nematoda: Ascaridida) based on three genes and morphology: hypotheses of structural and sequence evolution. J . Parasitol. 86, 380-394

25 Brooks, D.R. and D.A. McLennan, (1994) Historical ecology as a research programme: scope, limitations and future. In Phylogenetic Approaches to E col ogy (Eggleton, P. and Vane-Wright, R., eds), pp. 1-27, Academic Press

26 León-Règagnon, V. et al . (1999) Differentiation of Mexican species of Haematol oechus L ooss, 1899 (Digenea: Plagiorchiformes): combining molecular and morphological evidence. J . Parasitol . 85, 935-946

27 Hoberg, E.P. et al. Phylogeny among orders of the Eucestoda (Cercomeromorphae): integrating morphology, molecules and total evidence. In The Platyhel minthes - Phylogenetic Perspectives (Littlewood, D.T.J . and Bray, R.A., eds), Taylor \& Francis (in press)

28 Zamparo, D. et al. Phylogenetic analysis of the Rhabdocoela (Platyhel minthes) with emphasis on the Neodermata and relatives. Zool. Scripta (in press)

29 Brooks, D.R. and McLennan, D.A. (1992) The evolutionary origin of Plasmodium fal ciparum. J . Parasitol . 78, 564-566 